\title{
Representing "the other woman" in Instagram @trinitytraveler
}

\author{
Helen Diana Vida \\ Cultural and Media Studies, Postgraduate School, Universitas Gadjah Mada, Jl. Teknika \\ Utara, Yogyakarta, Indonesia, 55284 \\ e-mail: helendianavida@gmail.com
}

\begin{abstract}
Traveling is one activity that is often done by urban communities. Currently, there are many female travelers in Indonesia, one of them is Trinity that entered in a row of women who inspire Indonesian women. Trinity constructs self-identity by liberating herself from the construction of society in general and represents herself through social media, books and films. One of the used social media is Instagram, under account name @trinitytraveler. The purpose of these paper is to figure out how self-identity constructed and how the image of "Other Woman" is represented in @trinitytraveler. This research applied selfidentity theory from Anthony Giddens (1991) and representation from Stuart Hall (2013). Through @trinitytraveler, Trinity represents "The Other Woman" which is different from the "Ideal Woman" that has been known in the community. @trinitytraveler represents a different selfidentity; that is a single woman who has freedom of life by traveling to various places. In addition, @trinitytraveler also represents women who are able to enjoy and appreciate herself including her body, being freed from the dominant construction of beautiful women.
\end{abstract}

\section{Keywords}

representation, female traveler, Instagram, self-identity, other women

\section{Introduction}

The lives of people who live in big cities with various demands and high mobility in general lead to saturation in the social life of everyday

Citation: Vida, H. D. (2018). Representing "the other woman" in Instagram @trinitytraveler. In M. Amini, M. Yusuf, \& V. I. Yulianto. (Eds.), UGM Digital Press Social Sciences and Humanities: Vol. 1. Proceeding of the 2nd International Conference on South East Asia Studies, (pp. 33-41).

Published: October, 2018 society. Working and juggling all the pressure and demands, of urban life, has resulted in an urban awareness of the need for quality leisure time. From the various selection of activities to fill in leisure time, traveling is one of activity that can be selected. Traveling activity is being a transitional form or people breakout in transferring their boredom to face high social mobility.

Traveling activities have various types, such as shopping, nature tourism, historical tourism, culinary tourism and others. Traveling nowadays becomes a hobby and a primary need for many people, including women who live in urban areas. In the beginning, general traveling activity for women is shopping or traveling to places that usually visited by family members and common tourist attractions. As time passes, traveling activities performed by women become more 
challenging as it has been done by the male traveler and currently many female travelers start traveling alone or in a group of two people and no longer do it in a large member of groups. Traveling activities are done in many ways, start from traveling in public places, such as the beach, even to a quite extreme place, such as mountain climbing or diving.

One of the female travelers who is inspirational and popular in Indonesia is Riyanni Djangkaru, who then became the presenter of Adventurers' Impressions on Trans TV (formerly TV7) in 2002. In her television show, the places that she visited can be categorized as quite extreme, such as mountain climbing and deepsea diving. Riyanni's appearance in the show has inspired Indonesian women to be fearless traveling to extreme places. After the debut of Riyanni, female travelers with various interesting stories and experiences, more female traveler emerged such as Trinity, Marischka Prudence, Nadine Chandrawinata and Claudia Kaunang.

In order to portray female traveler fearlessness in their travelling activities, they use social media as one of the self-actualization media. Traveling activities performed by a female traveler that are uploaded in social media are considered as a way to show their existence. This is compatible with Yang \& Li' opinion (Sung et al., 2016, pp. 263) who said:

"A recent study found that individuals (especially females) fulfill their social needs through posting pictures of themselves on Social Networking Sites (SNS) because they expect to get responses from other users and have a brief chat with them".

Women show their identity and existence through various social media, such as Instagram.

Female travelers uploaded their photos on Instagram so people can see their activities and places that they have visited. Those pictures are for people to see and become interested to visit the place. As published in a news on Tribunstyle.com dated November 13,2016, a woman with diana_alexa account name copying a photo pose from a female traveler Instagram account with name gypsea_lust. In figure 1, we can see that @diana_alexa account uploads photos with the same outfit and place, even the same footsteps with @gypsea_lust account. Diana has uploaded more than five pictures in her Instagram account using the same outfit and also in the same place with @gypsea_lust picture.

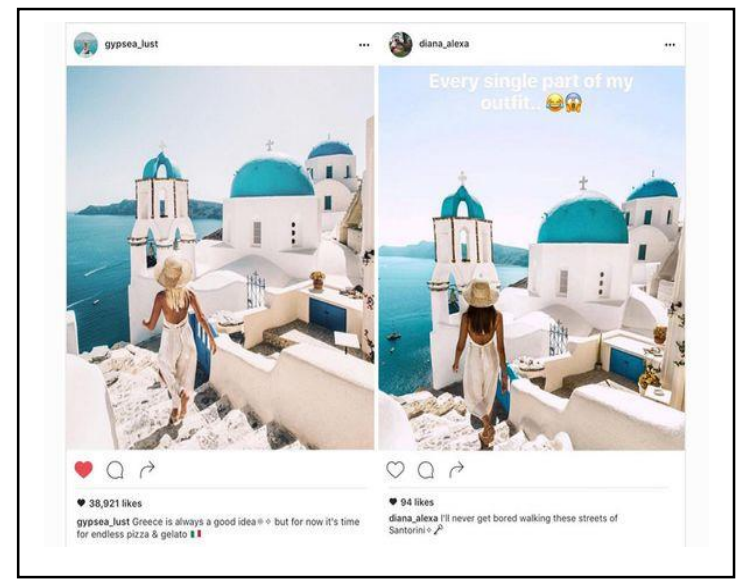

Fig. 1 Diana_alexa account uploads photos with the same outfit and place, even the same footsteps with gypsea_lust account (source http://style.tribunnews.com)

The use of social media as a media for communication, cannot be separated from the development of information technology. Lin \& Lu (Sung et al., 2016, p. 260) said:

"It's no longer news that social networking sites (SNSs) are now a major platform for communication, as well as for relationship management in daily life. SNSs are shown to have a significant impact on the social and cultural norms for communication and relationships by serving as a venue for individuals to present themselves, acquire information, and maintain relationships with others ".

Social media provides an important role in the life of today society, not only in terms of communication but also in providing space for self-actualization and getting information.

Today, social media developed in many kinds, such as Facebook, Twitter, Path and Instagram. Instagram has a specificity character on content in the form of images. Since its development in October 2010, Instagram is able to draw millions of people attention around the world to become its users and even beat 
the number of Twitter users who formerly became one of the social media that has many users. Lee et. al., (Sung et al., 2016, p. 260) said:

\footnotetext{
"Indeed the fast growing popularity of Instagram, with its more than 300 million users active monthly, has outperformed the text based twitter, which serves 284 million users, and fairly demonstrates that pictures speak louder than words".
}

On average, Instagram users share 150 photos a month, with more than 80 million photos and videos shared globally every day, and there are 3.5 billion likes per day (Herman dan YUD, 2016). According to the Country Director of Facebook Indonesia, Sri Widowati, Instagram users in Indonesia currently reach 45 million people and Indonesia became the largest Instagram community in the Asia Pacific (Andarningtyas, 2017). Hansal Savla, Senior Director of TNS Indonesia announced the research about "Instagram Users in Indonesia", where the majority users are young people aged 18 to 34 years with percentage $89 \%$ and the rest are 34 to 44 years. Instagram users in Indonesia are dominated by women with percentage $63 \%$, and male users only $37 \%$ (Herman dan YUD, 2016).

For traveling activities, Instagram becomes one of the social media which is used to show the existence of female traveler through their photos publication in Instagram, as done by one Indonesian female traveler Trinity, who published her traveling activity through various social media, including Instagram with @trinitytraveler as the account name. Trinity is a woman traveler who often writes her traveling experience through naked-traveler.com blogs since 2005, and in 2007 her blog posts were published as "The Naked Traveler 1". The word "Naked" actually does not mean literally to be naked but is a word game that means "Nekad". Until now, Trinity has written 13 with traveling theme, and in 2017 the "The Naked Traveler" book series produced into a movie.

Trinity, in her writing, not only write about the excitement and wonderful things which she encountered during her traveling activity, but also her insights and comments for the Indonesia tourism board. Until now, Trinity has been traveling almost to all provinces in Indonesia and has visited 80 countries in the world. Through traveling activities that have been done, Trinity gets various achievements, that is:

1. Eleven Indonesian Women's Emancipation Hero - Femina Magazine, 2017

2. Women Who Surpass Kartini Ideals - Jawa Pos Newspaper, 2014

3. Five Important People in Indonesia's Tourism World - DetikTravel Reader's' Choice, 2014

4. Inspirational Figure 2012 - Femina Magazine, 2012

5. Indonesia Most Influential Personality in Social Media, Category: Travel - SWA Magazine, 2012

6. Indonesia Tourism Hero - The Jakarta Post Newspaper, 2011

7. Seven Most Inspirational People in Tourism - Street Magazine, 2010

8. Indonesia Leading Travel Writer - Indonesia Travel \& Tourism Awards, 2010

9. Twelve Most Influential Indonesian Women on Twitter - Warta Ekonomi Magazine, 2010

With the various appreciations that she got, it is not surprising that Trinity becomes one of the Indonesian female travelers who inspired Indonesian women to perform various traveling activities as performed by Trinity. Through @trinitytraveler Instagram account, Trinity has 73,900 followers and has posted as many as 1554 images with almost all post images getting thousands of loves ( $\bullet$ ). The self-identity of Trinity as a single woman can be represented through her Instagram account a free and happy female figure.

The topic of self-identity, Instagram and traveling as research topic that is widely adopted today, including a work in Western Journal of Communication written by Eriko Maeda and Michael L. Hecht (2012, pp. 44-62) under the title "Identity Search: Interpersonal Relationships and Relational Identities of Always-Single Japanese Women Over Time ". This study aims to find out how single-women in Japan put themselves in a social environment, and how they perceive themselves as difference identity from people around them. The results of this study show that there is an evolution in the identity of single women in Japan, and self-acceptance through identity as single women and identity negotiation becomes an important thing to be accepted in the social environment.

The example of Instagram topics is written in the journal Sports Management Review written by Andrea Eagleman and Lauren Burch (2016, pp. 133-143) entitled "Communicating Via Photographs: A Gendered Analysis of Olympic Athletes' Visual Self-Presentation on Instagram". This study aims to find out how the Olympic athletes present themselves through Instagram. The results of this study indicate that female athlete prefer to share photos of themselves taken in the private sphere. While male athletes like to share various photos to get more support from their followers.

Moreover, the researcher discovers another research conducted by Megasari N Fatanti and I Wayan Suyadnya (2015, pp. 1089-1094) entitled "Beyond User Gaze: How Instagram Creates Tourism Destination Brand?". This study aims to explore in depth the presence of Instagram as a new communication media in 
the promotion of tourism in Indonesia. The results of this study show that the presence of Instagram as a media which has many private facilities that allow its users to upload what is seen in tourism sites, thus it becomes interesting to be shared to others. In addition, through the geo-tagging facility on Instagram, users can easily locate the location of tourism destination without wasting a lot of time.

Until today, the researcher has not found a study that discusses the topic of self-identity through traveling activities on Instagram post. This study based on assumption that photos which are posted through Instagram are considerate as a form of self-identity representation that presents "The Other Woman" which is different from the "Ideal Woman" that existed in Indonesian society. Based on that assumption, it is crucial to research on how self-identity that built-in Instagram @trinitytraveler and representation "The Other Woman" in Instagram @trinitytraveler.

\title{
2 Findings and Discussions
}

\subsection{Representation and Self Identity}

\author{
Giddens said that (Arne, 2014, p. 240):
}

"Self-identity is not a distinctive trait, or even a collection of traits, possessed by the individual. It is the self as reflexively understood by the person in terms of her or his biography ".

On the other hand, Giddens stated that identity is not something given naturally, but something created or constructed (Arne, 2014, p. 240). This definition of identity implies that people's reflection of their true identity is the core of what it means by the identity itself. For Lacan (Thornham, 2010, p. 108), as we have seen, the child's early recognition of himself in his own mirror image gives himself his first understanding of himself as a coherent identity and at the same time divides his identity into two, between who is portrayed (the Imaged) and who is portraying (the imaging self). Therefore, this is the self that constructed in representation and through identification.

In contrast to Giddens and Lacan, Kellner has another view as quoted by Rahayu (2006, p. 4) that in modern society, identity is more personal, which means that individual has the opportunity and role in determining the proper and appropriate identity for them. Identity is more related to style, to produce an image about how an individual wants to present itself, in determining and establishing then re-establishing identity as a possibility in modern society. Identity is no longer defined absolutely by society over the individual, so identity is a reflection of the individual self, no longer the absolute reflection of the social institution in which the individual is located. Then the identity in modern society is also still social, in this case, known as mutual recognition, where the identity of a person depends on the recognition of others in which combined with the self-validation of the interrelated individual then. Individual must attempt to gain recognition to achieve social legitimation of their selected identity which is recognized identity.

Rainwater as quoted by Giddens (1991, p. 75-80), explained that the search for identity in the modern era can be understood through several elements, which is:

1. The self is seen as a reflexive project, for which the individual is responsible. We are not what we are, but what we make of ourselves

2. The self-forms a trajectory of development from the past to the anticipated future

3. The reflexivity of the self is continuous, as well as all pervasive

4. Self-identity as a coherent phenomenon presumes a narrative: the narrative of the self is made explicit

5. Self-actualization implies the control of time - essentially, the establishing of zones of personal time which have only remote connections with external temporal orders

6. The reflexivity of the self extends to the body, where the body is part of an action system rather than merely a passive object

7. Self-actualizations is understood in terms of a balance between opportunity and risk

8. The moral thread of self-actualization is one of authenticity, based on being true to oneself

9. The life course is seen as a series of passages. The individual is likely or has to go through them, but they are not institutionalized or accompanied by formalized rites

10. The line of development of the self is internally referential. The key reference points are set "from the inside", in terms of how the individual constructs/reconstructs his life history 
Every individual has self-identity, that is how we think about ourselves and how we construct the whole narratives about "self" that usually become our fundamental (identity). The "self" identity can be perceivable as discursive construction and reflexive construction of "self," a story which we tell about ourselves. Identity cannot be separated from representation. The cultural discourse of "self" in the tradition of Western thought assumes that we have a true identity that we can recognize and express through some form of representation (Barker, 2014, p. 260).

Representation through photo tagging practices seems to represent objects or practice that occur in the "real" world, in other words, representation is an act of symbolism that reflects the world of independent objects. Representation in cultural studies not only reflects in the symbolic form "something" that exists in an independent object world, but the representation itself is constitutive of the meaning to be conveyed or to striven for. The power of representation lies in its ability to "enliven" some knowledge and "deadened" some other views (Barker, 2014, p. 255).

In order to make representation easier to understand it refers to two things, that is processes and products of creating signs to develop its meanings. Hall (2013, p. 10-11) said there are 3 approaches that can be used to understand the representation, which is:

1. The Reflective Approach, which says that meaning is understood as an object, person, idea or event in the real world, and language serves as a mirror that reflects the meaning in accordance with reality because that meaning has been attached to the related matter or the world itself

2. The Intentional Approach, says that the person delivering the message or the writer applying meaning to the world through language

3. The Constructivist Approach, says the meaning is not attached to the objects themselves, but rather we are giving and constructing meaning by using representational systems-concepts and signs.

\subsection{Representation in Instagram}

Instagram is currently used as one of the media to represent various things. Instagram is kind of application for photo-sharing and online social networking services that allow users to take pictures, apply digital filters, and allow users to link photos uploaded on Instagram to other various social media services like Facebook and Twitter.

According to Pittman and Reich (2016, p. 155), photographs uploaded through social media have millions of meanings compared to words, the message that wants to be delivered is considered faster conveyed than by using words. Uploaded photos can represent happiness and minimize the loneliness of its users.

Instagram as one of the social media has main features. That is: (1) Homepage, the main page displays a list of recent photos from other users who have been followed; (2) Comment, photos on Instagram can be commented in the comment field; (3) Explore, is the display of most popular photos that loved by other users on Instagram; (4) Profile, on the profile page we can learn in detail about the user information, as it is ourselves or others users; (5) News Feed, this feature displays notifications of various activities performed by Instagram users. Besides, Instagram also equipped with features such as title, hashtag, location, follow, like, comment, mentions (Atmoko, 2012, p. 28).

\subsection{Self-Identity in Instagram @Trinitytraveler}

Rainwater, as quoted by Giddens (1991, pp. 75-80), explains that the search for identity in the modern era can be considered through several elements, which also experienced by Trinity in obtaining her selfidentity. The first element, Trinity builds a story about herself. As Giddens (1991, p. 75) said, self-identity is not something naturally given, but something created or constructed. In this case, construction is not only done by the environment outside ourselves but also can be done by ourselves. As Kellner (Rahayu, 2006, p. 4) stated, in modern societies identity is more personal, which means that individuals have opportunity and role in determining the desired and appropriate identity for themselves. This is implemented by Trinity, she plays a role to determine self-identity accordance to her intention, for example by creating self-understanding that single women are able to relish life happily and travel anywhere they want to be. As said by Heimtun (2011, p. 83) traveling activities especially with backpacker style, is a traveling activity which is understood as a form of freedom and the life of single people. This is different 
with current understanding in society that women who are still single in the mature age are considered as women who are perceived as the other by their environment. As expressed by Lubis (2015, p. 107), women as adults must be married and responsible for taking care of their children and husband as their duty.

The second element as Giddens (1991, p. 75) says, the self forms a trajectory of development from the past to the anticipated future. Trinity builds herself and plans for her future. She leaves her career in the company courageously and pursues his dream by being a female traveler and writer. Likewise, in the third and fourth elements, Giddens (1991, p. 76) said the reflexivity of the self is continuous, as well as all pervasive and self-identity as a coherent phenomenon presumes a narrative: the narrative of the self is made explicit. Trinity continues and constantly develops herself, searching for new things and new places to visit. The process of self-development is always developed without interruption and updated constantly, and also described through various kind of writing and posting in social media and her books.

In the fifth to the tenth element from Giddens (1991, pp. 77-80), that emphasizes self actualization, reflexivity of the self extends to the body and in terms of how the individual constructs/reconstructs his life history, Trinity through it by sharing her experiences through social media, books and movies. Trinity presents herself visually through the @trinitytraveler Instagram account with a style that compatible her intention, as it is stated by Kellner (Rahayu, 2006, p. 4), identity is more related to the style, to produce an image that compatible with individual intention. This is the concept that implemented by Trinity to create an image according to her intention

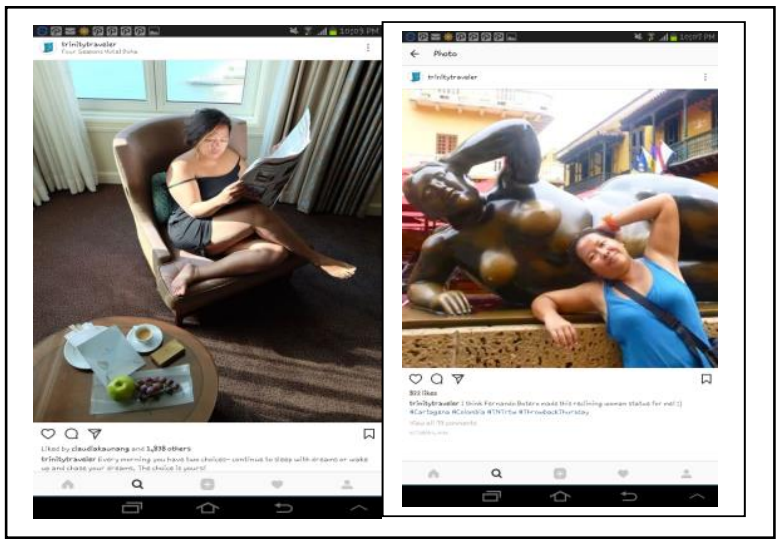

Fig. 2 Trinity with confidence expresses herself and her body (source: Instagram account @trinitytraveler)

In figure 2, Trinity shows her body posing with confidence and her expression portrayed through the picture, dauntlessly. Moreover, the caption which is written as "Every morning you have two choicecontinue to sleep with dreams or wake up and chase your dreams, the choice is yours" emphasizes Trinity's self-identity that enjoy her life and has full authority for herself.

\subsection{Representation “The Other Woman” on Instagram @trinitytraveler}

Trinity through @trinitytraveler Instagram account represents "The Other Woman" which is different from the "Ideal Woman" that has been constructed by society, in which the construction in society towards women associated to a fragile, emotional, and sentimental characters (Lubis, 2015, p. 107). Trinity breaks the construction by showing that women are not fragile and capable of doing things as men do, especially in traveling. In Instagram @trinitytraveler, it is shown that Trinity as a female traveler is able to stand on height and also dive in the deep ocean fearlessly. 


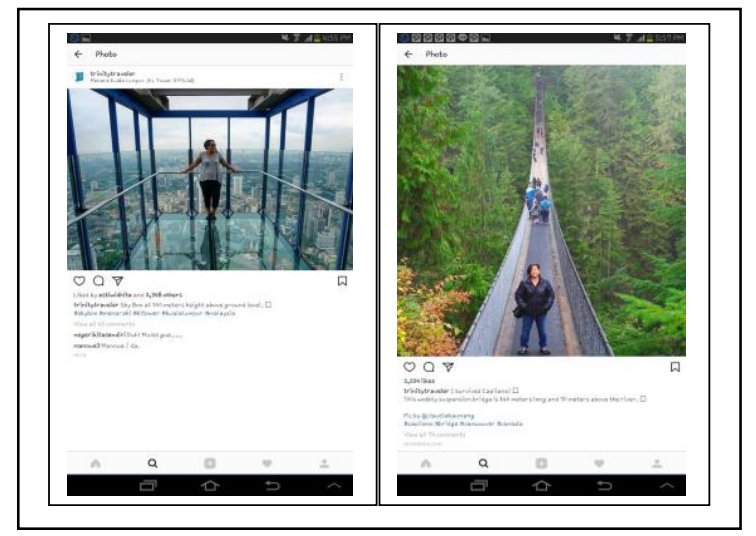

Fig. 3 Trinity dare to stand in tall buildings and suspension bridges (source: Instagram account @trinitytraveler)

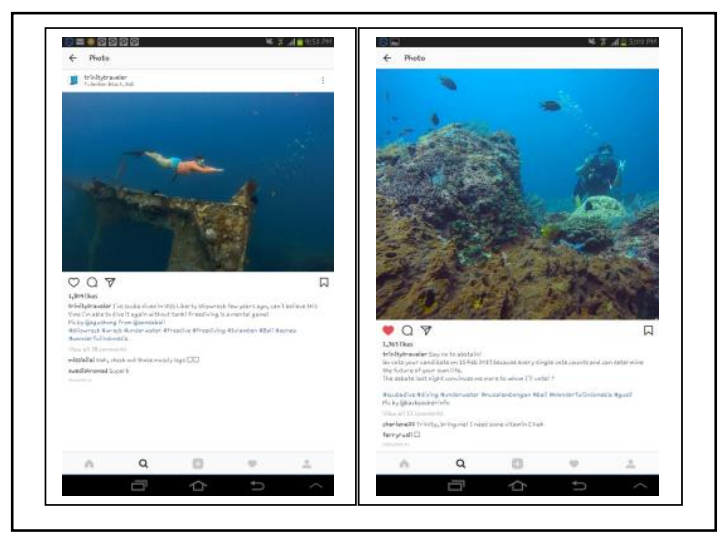

Fig. 4 Trinity dared to dive in the deep sea (source: Instagram account @trinitytraveler)

From figure 3 and 4, we can see how Trinity showed "The Other Woman" that broke the current construction of society. Even with the assumption that men are stronger and tougher than women is not proved, according to the post in picture 3 and 4, there are so many comments from men who said they do not dare to be in that height and for dive into the deep sea.

We can see another representation of "The Other Woman" in Instagram @trinitytraveler when Trinity posted a picture of herself with a sunburned skin, and her body is not as slim as the construction of society in common. In figure 5, we can see that Trinity proudly shows her body shape and skin color. She's not afraid to get sunburned and enjoy the beach using her pink outfit and still shows the feminine side. Lola Young as quoted by Hollows (2010, p. 181) said, the image of white European women as a standard of beauty that accepted globally, and it is adopted by most people in many parts of the world and create the image of beauty that identically refers to white skin and slim body.

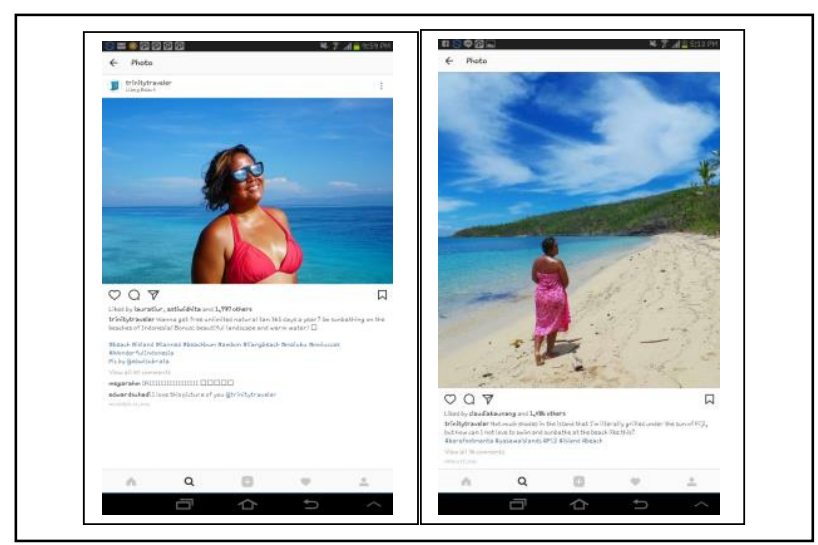

Fig. 5 Trinity proudly shows her body shape and skin color (source: Instagram account @trinitytraveler) 
All this time, the perception of the ideal woman is a woman who has a slim body and white skin. Thus women do not fit these criteria will be considered not ideal. As Prabasmoro (2006, p. 391) points out, the discourse of authority is noticed, when a person with the slim body as the owner of authority and a person with the big body as the "object of authority". One side is considered an ideal type when the other side is not. The ideal side is idealized themselves, while the not-ideal side is alienated from their own body. So that, many women are not free to play and swim at the beach or at sea because of their fear of having black skin. However, this perception is in contrast to Trinity, she shows her authority on herself and she prioritizes the satisfaction of enjoying the beach without think and afraid of her skin is burned and turn to black.

Trinity's Instagram; @trinitytraveler eradicates "Ideal Woman", she changes what has been idealized all this time and shows that "The Other Woman" can become the new "Ideal Woman". Trinity constructs what has been perceived and portray negatively all this time, which are for oversize and dark skinned women, into has a positive image. As Hall (2013, p. 17) says "It is underpinned by an acceptance - indeed, a celebration - of difference. It inverts the binary opposition, privileging the subordinate term, sometimes reading the negative positively: 'Black is Beautiful'. It tries to construct a positive identification with what has been objected".

The Trinity's "The Other Woman" representation does not stop the opportunity to be an "Ideal Woman" concept for single women. This can be seen from the many comments on Trinity's post on @trinitytraveler which content is complementing and trying to do what Trinity has been done, being a free woman who can travel anywhere and do whatever she wants. The "Ideal Woman" in society is no longer single, thereby today there are more options for women to choose their "Ideal Woman" she wants.

\section{Conclusions}

Based on the analysis conducted on the @trinitytraveler Instagram account, represents "The Other Woman" which is different from "Ideal Woman" which has been constructed by society. By putting aside society construction in general about "Ideal Woman", @trinitytraveler represents a different self-identity as a single woman who has freedom in her life by traveling to various places, local places and abroad. In addition, Trinity through her @trinitytraveler also shows herself as a woman who is able to enjoy and honor herself including her body, without having hegemonized by the construction of beautiful women who have a slim body and white skin.

"The Other Woman" which is represented through @trinitytraveler can be changed to "Ideal Woman" especially for single women who are constructed to enjoy their unmarried status by traveling and honor her body although her body is not slim, and her skin is not white. @trinitytraveler's representation is no longer a woman form of freedom, especially single woman, but can turn into a new hegemony portrayal of 'Single and Happy' women in Indonesia.

Through this research is expected to give knowledge and become the trigger to conduct a comprehensive and depth research on self-identity not only for women but also for men, which is represented not only in Instagram but also other social media or conventional media (television, newspaper, Magazines, and radio).

\section{References}

Andarningtyas, N. (2017). Pengguna Instagram di Indonesia capai 45 juta. [Instagram users in Indonesia reach 45 million]. Antaranews. [In Bahasa Indonesia]. Retrieved from www.antaranews.com/berita/642774/pengguna-instagram-di-indonesia-capai-45-juta.

Arne, B.Y. (2014). Positioning the self. Feminist Media Studies, 14(2), 237-252.

Atmoko, B.D. (2012). Instagram handbook tips fotografi ponsel [Instagram handbook: Smartphone photography tips]. Jakarta: Media Kita (p. 28). [in bahasa Indonesia].

Barker, C. (2014). Kamus kajian budaya [Dictionary of cultural studies]. Yogyakarta: PT. Kanisius (pp. 255, 260). [In bahasa indonesia]. 
Eagleman, A., \& Burch, L. (2016). Communicating via photographs: A gendered analysis of Olympic athletes' visual self-presentation on Instagram. Journal Sport Management Review 19, 133-145.

Fatanti, M.N., \& Suyadnya, I.W. (2015). Beyond user gaze: How Instagram creates tourism destination brand? Procedia-Social and Behavioral Sciences 211, pp. 1089-1095.

Giddens, A. (1991). Modernity and self-identity: Self and society in the late modern age. California: Stanford University Press (pp. 75-80, 240).

Hall, S., Jessica, E., Sean, N. (2013). Representation. London: SAGE Publication (pp. 10-11, 17).

Heimtun, B. (2011). The friend, the loner and the independent traveller: Norwegian midlife single womens's social identities when on holiday. Journal Gender, Place \& Culture (p. 83).

Herman \& YUD. (2016). Pengguna Instagram di Indonesia mayoritas perempuan. [Majority Instagram users in Indonesia are women]. Berita Satu. [In Bahasa Indonesia]. Retrived from www.beritasatu.com/iptek/341956-pengguna-instagram-di-indonesia-mayoritas-perempuan.html

Hollows, J. (2010). Feminisme, femininitas dan budaya populer. [Feminism, femininity and popular culture]. Yogyakarta: Jalasutra (p. 181). [In Bahasa Indonesia].

Hutomo, D.S (2016). Ngeri! blogger ini temukan perempuan yang meniru pose fotonya, persis banget! [Horible! this blogger finds women who mimic their photographs pose perfectly]. Tribunnews. [In Bahasa Indonesia]. http://style.tribunnews.com/2016/11/13/ngeri-blogger-ini-temukan-perempuanyang-meniru-pose-fotonya-persis-banget. Accessed 28 August 2017.

Lubis, A.Y. (2015). Pemikiran kritis kontemporer: Dari teori kritis, cultural studies, feminisme, postkolonial hingga multikulturalisme. [Contemporary critical thinking: From critical theory, cultural studies, feminism, poskolonial to multiculturalism]. Jakarta: Rajawali Pres (p. 107). [In Bahasa Indonesia].

Maeda, E., \& Hecht, M. (2012). Identity search: Interpersonal relationships and relational identities of always-single Japanese woman over time. Wester Journal of Communication, 44-62.

Pittman, M., \& Reich, B. (2016). Social media and loneliness: Why an instagram picture may be worth more than a thousand twitter words. Journal Computers in Human Behavior 62:155-167.

Prabasmoro, A.P. (2006). Kajian budaya feminis: Tubuh, sastra dan budaya pop. [Feminist cultural studies: Body, literature and pop culture]. Yogyakarta: Jalasutra (p. 391). [In Bahasa Indonesia].

Rahayu, T.P. (2006). Politik identitas anak-anak dalam iklan anak-anak. [Political identity of children in kids]. Media Masyarakat Kebudayaan dan Politik 19(2):4.[In Bahasa Indonesia].

Sung, Y., Lee, J-A., Kim, E., \& Choi, S.M. (2016). Why we post selfies: Understanding motivations for posting pictures of oneself. Journal Personality and Individual Differences 97:260-265.

Thornham, S. (2010). Teori feminis dan cultural studies. [Feminist theory and cultural studies]. Yogyakarta: Jalasutra (pp. 108). [In Bahasa Indonesia]. 